DOI: 10.2478/v10122-010-0005-y

\title{
THE HIEROGLYPHIC LUWIAN -si AGAIN
}

\author{
TERUMASA OSHIRO
}

\begin{abstract}
Aвstract. Terumasa Oshiro. The Hieroglyphic Luwian -si Again. Lingua Posnaniensis, vol. LII (1)/2010. The Poznań Society for the Advancement of the Arts and Sciences. PL ISSN 0079-4740, ISBN 978-837654-030-6, pp. 67-70

We recognize three attestations of the element $-s i$ attached to a verbal ending in KARKAMIŠ A11b, A12 and ALEPPO 2. The author has already regarded this -si as another reflexive element comparable to the reflexive - $t i$. Furthermore, we can also point out four more attestations of a similar element $-s i$ in the inscriptions recently discovered at TELL AHMAR 6: huhasata-si "he himself ran"(vii and xix) and at ÇINEKÖY: iziya-si "they themselves made" (vi and vii). It should be noted that the element $-s i$ in ÇINEKÖY is attached directly to an irregularly omitted verbal form iziya of *iziyanta "they made".
\end{abstract}

Terumasa Oshiro, Kyoto Sangyo University, Kamigamo-Motoyama, Kita-Ku, Kyoto 603-8555, Japan

It has been shown that the enclitic element $-s i$ is directly attached to verbal forms in Hieroglyphic Luwian inscriptions, the function of which the author has already confirmed as having a reflexive nuance comparable to the reflexive pronoun - $t i$ of this language. ${ }^{1}$ At that time there were only three attestations of the enclitic element $-s i$ as follows. KARKAMIŠ A $11 b, 3$ :

(vii) $a$-wa/i REL-a-ti-i (ANNUS) $u$-si-i $k a-w a / i-z a-n a(U R B S)$ (CURRUS)wa/i+ra/i-za-ni-ná $\mathrm{PES}_{2}$-za-ha

(viii) pa-tá-za-pa-wa/i-ta-' (TERRA+LA+LA)wa/i-li-li-tà-za mi-i-zi-' tá-ti-i-zi AVUS-hu-ti-zi-ha "384(-)la/ilu-tà-li-zi-ha $\mathrm{NEG}_{2}$-' $\left(\mathrm{PES}_{2}\right) H W I-H W I$-sà-tá- si

(vii) "In the year in which I carried (in) the city Kawa's chariot,

(viii) to those fields my fathers, grandfathers and ancestors themselves didn't march."

(2) KARKAMIŠ A12, 2:

(ii) $[\ldots . . . . .]-.t i-[z i]-h a \quad \mathrm{NEG}_{2}\left(\mathrm{PES}_{2}\right) H W I-H W I-s a ̀-t a-\quad s i$

(iii) mu-pa-wa/i-' (DEUS)TONITRUS-sa (DEUS)kar-hu-ha-sa (DEUS)ku+AVIS-pa-sa-ha PRAE-na PES $_{2}(-) w a / i-s a ̀-i-t a$

(iv) wa/i-tá-' (CURRUS)wa/i+ra/i-za-nína a-tá $\mathrm{PES}_{2}(-)$ wa/i-[z]a-ha

1 Refer to Oshiro (1993: 53-54), and Hawkins (2000 and 2006) who describes it as "still unexplained". As for various kinds of Hieroglyphic Luwian particles, see CARRUBA 1969, MelChERT 1988, Plöchl 2003 and PAYNE 2004. 
(ii) "[To those fields my fathers] and [grandfath]ers themselves didn't march,

(iii) but the gods Tarhunt, Karhuha and Kubaba walked(?) before me,

(iv) and I carried in the chariot."

The element -si in KARKAMIŠ A1 $b$ and A12 cited above is surely attached to the verb $\left(\mathrm{PES}_{2}\right) H W I-H W I-s a(n) t a$ "they marched" parallel to Cun.Luw. verb $h u(i) h u(i) y a$ - "run" and appears to indicate some reflexive nuance of "their own marching". 2

\section{ALEPPO 2, 3:}

(vii) mu-pa-wa/i-' URBS-ni-zi-' $\mathrm{NEG}_{2}{ }^{-}$[ [.........]

(viii) wa/i- mi-' (DEUS)SOL-ni-za ("LIGNUM")ta-ru-sa i-zi-i-ha- si

(ix) a-wa/i mi-na-’ FRATER-la-na 'ha-mi-i[a]-ta-ná $\mathrm{NEG}_{2}{ }^{-’}$ [......... $]$-ha

(vii) "And me the cities [...]not[...].

(viii) I made an image of the Sun-God completely by myself.

(ix) I didn't [...] my brother, Hamiyata."

The element -si of (viii) cited above is attached to the verb iziha "I made" in the final position of the clause. Furthermore, the enclitic - $m i$ of the initial phrase $w a / i-m i$-' is regarded as the 1.sg. enclitic pronominal form with a reflexive nuance. Thus, the element $-s i$ is considered as a redundantly attached reflexive element. ${ }^{3}$

Therefore, -si may show an emphatic reflexive nuance by attaching directly to the verbal form and may correspond to the reflexive enclitic pronoun -si in Palaic as follows.

Palaic: KUB XXXII 18:

(vi-vii) a-an- ti -en-ta ma-a-ar-ha-as a-ta-a-an-ti ni-ip-pa- $s i \quad$ mu-sa-a-an-ti

(vi-vii) "And gods themselves (-ti) eat it, but they themselves (-si) are never satisfied."

Furthermore, we can also attest the enclitic element -si in the new inscriptions recently discovered at Tell Ahmar and at Çineköy, which is surely attached to verbal phrases. At present there are four attestations of the element -si as follows:

TELL AHMAR 6:4

(vii) PRAE-pa-wa/i-mu za-a-sa EXERCITUS-la/i/u-na-si-sa (DEUS)TONITRUS-sa $h u-h a-s a ̀-t a-s i$

(vii) "This Tarhunt of the Army himself ran before me."

\section{TELL AHMAR 6:}

(xvii) za-a-sa-pa-wa/i-mu EXERCITUS-la/i/u-na-si-i-sa (DEUS)TONITRUS-sa (LITUUS)á-za-ta

(xviii) wa/i-ma-sa-' LITUUS' $+n a^{3}$-hi-i-tà VIA-hu-sa-la-hi-tà-ha wa/i+ra/i-li-ta

(xix) wa/i-ma-sa-' PRAE-na hu-ha-sà-ta- si

(xvii) "But this Tarhunt of the Army loved me,

(xviii) and he made me (his) own in vision(?) and in [...]-ing(?),

(xix) and he himself ran before me."

2 The preconsonantal - $n$ - of $\left(\mathrm{PES}_{2}\right) H W I-H W I-s a(n)$ ta "they marched" is omitted in Hieroglyphic Luwian.

3 Refer to the reflexive particle - $t i$ directly attached to the verbal forms in Cuneiform Luwian: KUB XXXII 9, Rs.16 and KUB XXVII 26, 6: i-li-il-ha-i- til/ il-ha-ti- tit]"he washes himself."

4 Cf. Hawkins 2006: 11-31. 
The element -si attached to the verb huhasata "he ran" cited above is also considered as an enclitic reflexive element, the form of which is contextually parallel to those in KARKAMIŠ A11 $b$ and A12.

In addition, this element is also attested in the Phoenician-Hieroglyphic Luwian bilingual text at Çineköy, though we must clarify an exceptional verbal phrase, $i$-zi-ia-si, in detail.

\footnotetext{
ÇINEKÖY:5

(vi) REL-pa-wa/i-mu-u su+ra/i-wa/i-ni-sa(URBS) REX-ti-sa su+ra/i-wa/i-za-ha(URBS) DOMUSna-za ta-ni-ma-za tá-ti-na MATER-na-ha $i-z i-i a-s i$

(vii) hi-ia-wa/i-sa-ha-wa/i(URBS) su+ra/i-ia-sa-ha(URBS) "UNUS"-za DOMUS-na-za i-zi-ia-si
}

By contextual analysis of the citation above, the subjects of both (vi) and (vii) are clearly plural; (vi): Surawanis(URBS) REX-tis Surwa(n)za-ha(URBS) DOMUS-na(n)za tanima(n)za "the king of the Suraya citizens and the entire house of the city Suraya" and (vii): Hiyawas(URBS) Surayas-ha(URBS) "the city Hiyawa and the city Suraya". Furthermore, in view of the Phoenician part of the ÇINEKÖY inscription, the verbal phrase iziyasi is very probably understood as corresponding to the 3.pl.pret. verb $K N$ in Phoenician; (7-10): "Et le roi [d'Assur et] toute la maison d'Assur ont été pour moi un père [et une] mère. Et les Danouniens et les Assyriens ont été une seule maison". 6 Thus the verbal phrase iziyasi can be divided into iziya and -si, that is, iziya is an exceptionally omitted verbal form of the 3.pl.pret. *iziya(n)ta "they made" ance for "themselves". In this case, the final -ta of the 3.pl.pret. verbal ending *- $n$ )ta of *iziya(n)ta is wrongly omitted for consecutive alveolar/dental *-ta-si. We can surely understand the above-mentioned forms $\left(\mathrm{PES}_{2}\right) H W I-H W I$-sà-ta-si(<*huihuisanta-si), $i$-zi$i$-ha-si $(<* i z i h a-s i), h u$-ha-sà-ta-si $(<* h u h a s a t a-s i)$ and $i$-zi-ia-si $(<* i z i y a n t a-s i)$ as respective verbs with an enclitic reflexive -si, never as full verbal forms suggested by RIEKEN (2004). ${ }^{8}$

Thus the author's tentative translation is as follows:

(vi) "And so the king of the Suraya citizens and the entire house of the city Suraya themselves made father and mother for me.

(vii) And the city Hiyawa and the city Suraya themselves made one house."

In summary, it is to be noted that the enclitic $-s i$ is another reflexive element parallel to the reflexive pronoun - $t i$ in Hieroglyphic Luwian.

5 Cf. TekoĞLu \& Lemaire 2000. The author is very thankful to Dr. Annick Payne (Würzburg) for obtaining copies of this article.

6 See TekoĞLu \& Lemaire 2000: 978-980 and 994.

77 The preconsonantal - $n$ - of the 3.pl.pret. *iziya(n)ta "they made" is omitted in Hieroglyphic Luwian.

8 Cf. Rieken 2004. 


\section{REFERENCES}

Carruba Onofrio. 1969. Die Satzeinleitenden Partikeln in den Indogermanischen Sprachen. Roma: Edizione dell'Ateneo.

CARruba Onofrio. 1970. Das Palaische Texte, Grammatik, Lexikon. Wiesbaden: Harrassowitz Verlag.

HAwKINS John David. 2000. Corpus of Hieroglyphic Luwian Inscriptions. Vol. I. Berlin: de Gruyter.

Hawkins John David. 2006. A New Luwian Stele and the Cult of the Storm-God at Til Barsib-Masuwari. Louvain: Peeters.

MelCheRT H. Craig. 1988. “'THORN'and 'MINUS'in Hieroglyphic Luwian Orthography.” Anatolian Studies $38,29-42$.

Oshiro Terumasa. 1993. "Notes on Hieroglyphic Luwian." Orient 29, 45-56.

Payne Annick. 2004. Hieroglyphic Luwian. Wiesbaden: Harrassowitz Verlag.

PLÖCHL Reinhold. 2003. Einführung ins Hieroglyphen-Luwische. Dresden: DBH Band 8.

RIEKEN Elisabeh. 2004. "Das Präteritum des Medio-Passivs im Hieroglyphen-Luwischen." Historische Sprachforschung 117, 179-188.

TeKoĞLu R., Lemaire A. 2000. "La bilingue royale louvito-phénicienne de Çineköy.” Académie des Inscriptions \& Belles-Lettres, comptes rendus, 961-1007.

Allatum die 3 mensis Augusti Anno 2009 